\title{
OPPOSITIONAL MOVEMENTS IN EGYPT, FROM 1952 TO MUBARAK'S DOWNFALL
}

\author{
Josep Puig Montada \\ Universidad Complutense ${ }^{1}$
}

Summary.- Account of the main oppositional movements in Egypt, since Nasser's rise to power until Mubarak's downfall, considering both Islamist and secularist organizations and their relationship.

Keywords.- Egypt, contemporary history, Nasser, Sadat, Mubarak.

On 30 June 2012, the first civilian president of Egypt was sworn into office; Mohammad Morsi was also the first president of the country elected in fair polls. After the military coup of 23 July 1952, led by Gamal 'Abdel Nasser', Egypt did not experience a democratic form of government until the revolution of January 2011.

For 60 years, the Egyptian army kept control of a country of now over 80 million people. That the regime remained so long in power can be explained by the long-lasting conflict with Israel, by widespread repression, and by the capacity to create a network of vested interests, adapting to new social and economic situations. However, the lack of effective oppositional movements was also a contributing factor to the long life of authoritarian rule extending through the presidencies of Nasser, Sadat and Mubarak.

1. When King Farouk signed the Act of Abdication on 25 July 1952, a Regency Council was established to maintain the appearances of kingship while preparing for the inevitable republic. The effective power was in the hands of the Revolutionary Command Council $(\mathrm{RCC})^{3}$, whose leader was General Mohammad Naguib, although Nasser was the most influential member. On 11 October of that same year, the new regime set free all political prisoners. On 18 January 1953, the military leaders made a decision of far-reaching consequences: They abolished all political parties, paving the way for dictatorship. The Muslim Brotherhood was not considered a political organization and therefore was not affected by the prohibition. To replace political parties and to back the new regime, the organization Hay'at al-tahrîr (Liberation Board) was founded.

When the monarchy was abolished on 18 June 1953, General Mohammad Naguib became the first president and Prime Minister of the republic. Naguib never belonged to the hardcore of the Free Officers who started the coup. He

\footnotetext{
${ }^{1}$ I thank Patricia Guenther-Gleason, ThD, Claremont CA for help with revising the text. All errors are mine.

${ }^{2}$ I have not followed scholarly transliteration rules for personal names that are best known through the English press or books.

${ }^{3}$ Equal to the thirteen-man executive committee of the Free Officer's movement.
} 
resigned on 23 February 1954 because of disagreements with the RCC, and he was put under house arrest. The vice-chairman of the RCC and Deputy Prime Minister, Gamal 'Abdel Nasser, swiftly replaced him.

There was some opposition to the new regime from the supporters of the former regime as well as from those who were disappointed by the new rulers. The old ruling class of Pashas and Beys was soon removed from power.

The Muslim Brotherhood and the Wafd party - the party of the land owners ${ }^{4}-$ were the only two groups to survive the coup with any degree of mass support. Additionally, the Communist party, a few leftist organizations, student groups and trade unions offered some disorganized resistance. When a strike was organized in August 1952, the Free Officers did not hesitate to execute the labor leaders Mostafa Khamis and Mohammad Hasan el-Bakary.

Thus when the news of Naguib's removal from power spread over Cairo, large popular demonstrations erupted in his favor. The Muslim Brotherhood was outlawed on 14 January 1954. There had been clashes between opposing student groups the day before, and the government seized its chance to prohibit the Muslim Brotherhood that nevertheless remained strong ${ }^{5}$. The Brotherhood united with the remaining elements of the Wafd party in favor of Naguib. More importantly, Naguib's partisans in the army led by Khaled Mohieddin, a liberal Marxist officer, emerged as the stronger force, and Nasser had to accept Naguib's return to the presidency.

Nasser did not give up, however, and organized a second coup, "a masterly combination of force and political finesse". . Officers sympathizing with Khaled Mohieddin were isolated. The most active elements among the Muslim Brotherhood were arrested. A press campaign stressed General Naguib's involvement with the ancien régime and stirred fears of its reappearance. Demonstrations were arranged opposing liberalization. Major Tu'ayma organized the decisive demonstration of the transport workers.

Nasser showed that he held the keys to power - in the army, among the workers and in the streets - and he forced Naguib to resign as Prime Minister on 17 April 1954. Soon, an assassination attempt on his own life would help him to get rid of both Naguib and the Muslim Brotherhood, the best organized oppositional movement.

On 26 October 1954, a member of the Muslim Brotherhood named Mahmoud 'Abdel Latif fired six shots at Nasser while he was speaking at a public meeting in Alexandria. Two men next to Nasser were hit, but he was unharmed. The Supreme Guide of the Brotherhood, Hasan el-Hodeiby, denied the Brotherhood's responsibility for the assassination attempt, but the Muslim Brotherhood was finally banned ${ }^{7}$. Mass arrests were conducted. A special court

\footnotetext{
${ }^{4} 6$ per cent of the total landowners in Egypt owned 65 per cent of the land. Gabriel Baer, $A$ history of Landownership in Egypt, 1800-1950. New York: Oxford UP, 1962.

${ }^{5}$ Hâla Mușțafà, Al-dawla wa-l-harakât al-islâmîya al-mu 'âraḍa bayn al-muhâdana wa-lmuwâjaha, "The state and the Islamic movements, between truce and confrontation" (Cairo: Merit, 1999), p. 132.

${ }^{6}$ Robert Stephens, Nasser. A Political Biography (New York: Simon and Schuster, 1971), p. 127.

${ }^{7}$ Maxime Rodinson, "The Political System" in P.J. Vatikiotis, ed. Egypt since the Revolution (London: Allen, 1968), p. 102.
} 
whose three members were Gamal Salem, Anwar al-Sadat, and Hossein alShafi i $i$ was arranged to try the conspirators. On $1^{\text {st }}$ November 1954 , the court sentenced to death and executed the following six Ikhwân: Mahmoud 'Abdel Latif, Yusuf Tal'at, Hindawy Duwayr, Ibrahim al-Tayyeb, 'Abdel Qader 'Awda, and Mohammad Farghaly.

The Supreme Guide of the Ikhwân, Hasan al-Hodeiby, was also sentenced to death, although he was not executed. On 14 November Naguib was removed from his office as president. This time, however, there were no demonstrations in the streets or agitation in the army. A military dictatorship was firmly established, and it would last for 60 years. The Hay'at al-tahrîr was replaced by the National Union on 28 May 1957, and the latter in turn by the Arab Socialist Union (ASU) on 7 December 1962. However, these political organizations proved to be unstable, and true power remained in the hands of the military ${ }^{8}$.

Nasser proclaimed that "socialism is our only road to justice" in a televised speech to the nation on 16 October 1961. Once-prominent people were arrested and hundreds had their property confiscated, among them Fouad Serag el-Din, former Wafd secretary general ${ }^{9}$. The exodus of people of foreign or minority origin flowed. The Press was nationalized and placed under tight control $^{10}$.

Nasser's opposition was not united. From 1959 to 1964, the left suffered horribly in Egypt. Among those brutally murdered was their theoretician, Shohdi 'Attiya al-Shafe'i. In 1965, the Egyptian Communist Party officially dissolved and the communist left joined the ASU. After the 1967 defeat, the regime turned once again against the left.

The Arab Socialist Union (ASU) was the only legal political organization in the country. Their members defended a policy of heavy industrialization, state socialism, and close cooperation with the Soviet Union. But they were faced with the army officers within the regime. "The last years of Nasser's rule were marked by rising tension between the military/ police and the leftists who argued for a truly effective political party". ${ }^{11}$ Nasser never identified himself completely with the ASU, and the regime was mostly autocratic. The prominent philosophy professor Fouad Zakariyya (1927 - 2010) indicted the Nasser regime for "the inner destruction of the Egyptian soul". 12

The High Dam and its power station were completed in July 1970. Their completion improved the image of Gamal Abdel Nasser, but he did not benefit from this for too long; he died on 28 September 1970.

\footnotetext{
8 Panagiotis J. Vatikiotis, The Egyptian Army in Politics: Pattern for New Nations? Bloomington: Indiana UP, 1961.

${ }^{9}$ Stephens, Nasser, p. 346.

${ }^{10}$ Al-Mișî, the organ of the Wafd party was banned already in 1960.

${ }^{11}$ Raymond W. Baker, Egypt's Uncertain Revolution under Nasser and Sadat (Harvard UP, 1978), p. 86.

${ }^{12}$ Fouad Zakariyya would be a leading advocate for secularism in the Arab world. After the assassination of Sadat he published the book, translated into English as Myth and Reality in the Contemporary Islamic Movement, London: Pluto Press, 2005, criticizing the Islamist movements.
} 
2. Anwar al-Sadat (born 1918), a fellow Free Officer, was Nasser's vicepresident since December 1969, and upon his death succeeded Nasser as the new president of Egypt. Little more than six months elapsed before Sadat launched the "Corrective Revolution" to dismantle a plot lead by "Ali Sabry, an air force officer. The conspirators, known as the "centers of power", were behind the Arab Socialist Union.

On 28 December 1970 Sadat abolished sequestration, seizure by the state of the property of individuals who were politically out of favor. The number of political prisoners reached as high as twenty thousand in the sixties. During the first years of Sadat's rule, virtually all political prisoners were released. Sadat reached out to the Muslim Brotherhood and negotiated with 'Omar al-Tilimisani, its guide ${ }^{13}$.

Sadat rehabilitated Mostafa Amin, who had been arrested by Nasser's muhâbarât and had been incarcerated since $1965^{14}$. His brother 'Aly replaced Mohammad Hassanein Haykal as editor in chief of al-Ahrâm. 'Aly and Mostafa Amin were made editors of al-Akhbâr and Akhbâr al-Yawm, the newspapers they had founded in 1944.

In the Egypt of Sadat as of Nasser, real power rested with the military / police complex. However, some changes took place: In the tense spring of 1975, Sadat replaced Hussein al-Shafe'i, the last of the RCC members still in power, with Hosni Mubarak.

The Arab Socialist Union was tamed, but it did not fulfill any positive function. Ihsan 'Abdel Qudus (1929-1990), the journalist closest to Sadat, wrote in alAhrâm: "In reality the ASU is an official organization". ${ }^{15}$ Sadat tried to give it some structure and functionality, and early in 1976 created three platforms: the right was headed by Mostafa Kamal Mourad, a cotton broker, the center by Mamdouh Salem, Sadat's prime minister, and the left, by the "red colonel", Khaled Mohieddin. In the parliamentary elections of 1976, the right gained 12 seats, the left 2 seats, and the center 280 seats.

Real opposition has to be looked for in other places. In March 1975, forty thousand textile workers went on strike in Mahalla. In September of 1976, striking bus drivers battled army strike-breakers. In November 1976, five hundred students demonstrated, demanding to be allowed to form parties ${ }^{16}$.

Sadat's attempts to steer the political process failed also among students. AlGama'a al-islamiyya was an organization of Islamic militant student groups. To counterbalance the Nasserite and Marxist groups predominant at the universities and critical to him, Sadat helped the Gama' al-Islamiyya to spread and grow in influence (1973).

The name for Sadat's economic program is Infitâh, or "opening". Its aim was to achieve a consolidation of the public sector and at the same time to promote private sector growth. Nevertheless, the open door policy brought rampant inflation and consequent hardship to most of the population.

\footnotetext{
${ }^{13}$ Dhikrayât, lâ mudhakkirât (Cairo: Dâr al-i'tișâm, 1985), p. 61.

${ }^{14}$ The First Year in Prison, Cairo, 1974. Mostafa Amin (d. 1997) was freed in 1974.

${ }^{15}$ Baker, Egypt's Uncertain, p. 163.

16 Ahmed Abdalla (Manar Shorbagy, introduction), The Student Movement and National Politics in Egypt, 1923-1973, (1985), Cairo:AUC, 2008.
} 
On 17 January 1977, the government announced plans to cancel around 277 million Egyptian pounds worth of subsidies on basic commodities, as well as the cancellation of bonuses and pay raises for state employees. The reduction was due to pressure mainly from the IMF and the USA. This immediately led to high price increases. On 18 and 19 January, 1977, massive demonstrations erupted in Egypt's cities. Within just two days, rioting and strikes occurred in most major cities and industrial towns of Egypt; the headquarters of the ruling Egypt Arab Socialist Party in Cairo was attacked. Prime Minister Mamdouh Salem indicted the Egyptian left and the party of Khaled Mohieddin. However Rose al-Yussef dissented from the official claim that the riots were leftist inspired ${ }^{17}$. Sadat removed the editorial boards of both Rose al-Yussef and al-Tali'a.

The conservative Arab states and the USA allocated aid funds to meet the crisis. One must take into account that Egypt's agriculture had not kept pace with the growth of the population.

In 1977, the indicator for value added reached a minimum value of -2.79 after it had reached a maximum value of 8.07 in $1972^{18}$. The average income of the peasants was the lowest. Illiteracy reached $70 \%$ in the seventies. Sadat showed little real interest in the peasants' cooperatives after Nasser's agrarian reform did not achieve the goals that were expected.

Sadat enacted Law 40/1977 to regulate the formation of political parties ${ }^{19}$. Following its enactment, several political parties were created. The ASU metamorphosed into the National Democratic Party. The right platform gave birth to the Hizb al-ahrâr, the Liberal Party. The left platform produced the National Progressive Unionist Party, Hizb al-tagammu', headed by Khaled Mohieddin. The Nasserist imprint was obvious in the latter.

In February 1978, the pre-Nasser Wafd was revived and Mohammad Fouad Serag al-Dîn became the new secretary general. In spite of having only 22 deputies, the New Wafd made its voice heard in the parliament. The Wafd objected to the peace negotiations with Israel, and Sadat cracked down on the organization. Later in the same year it was forced to disband ${ }^{20}$.

The Socialist Labor Party, now the Islamic Labor Party, was founded in 1978, with a leftist orientation. It was meant to co-opt the constituency of the National Progressive Unionist Party, but it turned into a solid opposition.

In 1979, parliamentary elections took place with the participation of the new registered parties. Under its new name of National Democratic Party (NDP), the government party won $92 \%$ of the seats!

On 20 November 1977, Anwar Sadat addressed the Knesset in Jerusalem, and in September 1978 he signed the Camp David agreements. Six months later the peace treaty was concluded between Egypt and Israel. A referendum on "peace and democracy" was held in April 1979 to ratify the treatise; the Parliament was disbanded shortly thereafter.

Although most Egyptians accepted Sadat's policy, opposition widened in the period following the treatise. Sadat's position was endangered by opposition

\footnotetext{
17 http://www.rosaelyoussef.com/articles/435/ معركة_الشرقاوى-مع-السادات Accessed Sept. 2013.

${ }^{18} \mathrm{http} / / / \mathrm{www}$.indexmundi.com/facts/egypt/agriculture Accessed Sept. 2013

${ }^{19}$ Noha el-Mikawy, The Building of Consensus in Egypt's Transition Process, Cairo: AUC, 1999.

${ }^{20}$ Raymond A. Hinnebusch, Egyptian Politics under Sadat, (Cambridge UP 1985), p. 219.
} 
from all directions. In September 1981 he resorted to repression, and at least 1536 oppositional members from across the political spectrum were arrested ${ }^{21}$. 'Omar al-Tilimsani, the Guide of the Muslim Brothers, was among them ${ }^{22}$.

On 6 October 1981, four enlisted men, an army major, 'Essam al-Qamari, and a lieutenant, Khaled El-Islambouli, opened fire at Sadat and his entourage while he was reviewing the military parade celebrating the Yom Kippur war. Al Gama'a al-Islamiyya, a Brotherhood offshoot, had plotted the attack ${ }^{23}$. Khaled El-Islambouli, Mohammad al-Salam Farag, 'Essam al-Qamari and three other co-conspirators were executed on 15 April 1982.

3. Vice-president Mohammad Hosni Sayyid Mubarak was sworn in as President on 14 October 1981, eight days after the Sadat assassination. He declared at that time the "emergency law", 24 a martial law that would last throughout his presidency. "At the close of the Sadat era, the huge authoritarian-bureaucratic state which Nasser built remained largely intact". ${ }^{25}$ Mubarak, however, liberated most of the prisoners incarcerated by Sadat in the month prior to his assassination.

Mubarak wanted to continue the Inftitâh but maintain the food subsides. His main success during his first years in office was restoring balance in Egypt's foreign policy and in particular, restoring ties with the Arab world. In 1980, Iraq launched a war against Iran that lasted until 1988, and Mubarak supported the Iraqi cause; many Egyptian expatriates were employed by Iraq during the war.

3.1. The first parliamentary elections under the new regime took place in May 1984 according to a new electoral law. According to this law, no parties were allowed representation unless they obtained $8 \%$ of all national votes. All seats obtained by parties that did not reach the percentage were added to the winning party. Mubarak's National Democratic Party obtained $72.9 \%$ of the votes and $87 \%$ of the seats, 390 out of 448 .

The parliamentary opposition could never be successful under such rules, not to mention the tricks used by the authorities, but it participated in the elections. The Muslim Brotherhood formed an alliance with the New Wafd in the 1984 elections and received 58 seats.

In February 1986, the Central Security police force mutinied; it looted and set fire to night clubs and luxury hotels ${ }^{26}$. The origins of the 1986 mutiny have never been made clear. It has been said that the rioting security police, all of them draftees, were furious over a rumor that their tours of duty were being extended by a year, from three years to four. Civilians joined in the arson and looting, shouting Islamic slogans. Police and soldiers, backed by tanks, put down the mutiny with brutal efficiency. Mubarak survived and even cemented his power.

\footnotetext{
${ }^{21}$ Salah Montasar, Al-șu 'ûd wa-l-suqût, $3^{\text {rd }}$ ed. (Cairo: al-Mișrî al-Yawm, 2011), p. 70.

${ }^{22}$ Ayyâm ma' al-Sâdât (Cairo: Dâr al-I'tișâm, 1984), p. 5.

23 'Aboud al-Zomor, a military intelligence officer was the leading figure of Al-Gama'a alIslamiyya. See his views in March 2011: http://www.memrijttm.org/clip_transcript/en/2868.htm

${ }^{24}$ Law No. 162 of 1958.

${ }^{25}$ Hinnebusch, Egyptian , p. 78.

${ }^{26}$ Salah Montasar, p. 119
} 
In April 1987, new elections were held to pre-empt a decision by the judiciary declaring unconstitutional the composition of the existing Parliament. The ruling party won "only 309 seats" in addition to 40 seats of so-called independents. During the 1987 elections, the Muslim Brotherhood formed an alliance with the Socialist Labor Party and they both obtained 56 seats. Mubarak was reelected when his National Democratic Party won the elections and appointed him as the only candidate ${ }^{27}$.

The "Salsabil case" is often used to mark the beginning of the confrontational stage between President Hosni Mubarak's regime and the Muslim Brotherhood $^{28}$. In 1983, Hasan Malek and Khairat Shater cofounded one of Egypt's first software companies, "Salsabil", which signed the Egyptian military as one of its clients. In 1992, its three owners, Shater, Malek and Mahmud 'Ezzat, all belonging to the Muslim Brotherhood, were arrested under the accusation of gathering sensitive strategic information.

3.2. Iraqi troops invaded Kuwait on 2 August 1990. Saddam Hussein claimed that Kuwait was slant-drilling across the border into Iraq's Rumaila oil field, and also accused Kuwait of other attacks on the economy of Iraq. Egypt condemned the invasion and sent troops to join the coalition forces that liberated Kuwait in January 1991. In this way, Mubarak won a reputation as an international statesman and his country enjoyed the material favor of the rich oil countries. A significant portion of the national debt was forgiven and rescheduled. His administration began reforms to reorganize the financial sector and encourage free trade, promoting privatization and private sector development.

As for the internal politics, not everything looked so promising. In June 1991, ten opposition parties including the Muslim Brotherhood signed a 10-point joint statement calling for a new constitution that would establish an effective parliament ${ }^{29}$. Their force as opposition was trifling, and Mubarak was reelected to a third six-year term in 1993.

There are 21 syndicates in Egypt. The most active and semi-independent are the bar association, the journalists, the medical doctors, and the engineers' associations. Syndicates were mainly dominated by the Muslim Brotherhood throughout the 1980s and 90s; however, the state enacted Law 100/1993 (and Law 5/1995 with amendments) to hamper the Islamists' hegemony in these syndicates, which became dominated by members of the then-ruling National Democratic Party

'Abdel-Harith Madani had represented defendants accused of involvement with al-Gamâ'a al-Islamîya, a group waging an armed rebellion against the government of Mubarak. In the evening of 26 April 1994, the police raided his

\footnotetext{
${ }^{27}$ Under the 1980 amendments of the 1971 Egyptian Constitution, the president of the republic was elected indirectly in a two-stage system unique to Egypt. The People's Assembly, the lower house of Parliament, nominated one of a number of candidates for presidency. The presidential candidate requires at least a two-thirds majority in the People's Assembly in order to proceed to the second stage of the elections.

${ }^{28}$ Middle East Contemporary Survey, ed. Ami Ayalon, vol. 16, (Tel Aviv: 1992), p 374.

${ }^{29}$ www.hrw.org/reports/1992/.../MEW1-01.html Accessed Dec. 2012.

Middle East Contemporary Survey 1991, ed. Ami Ayalon, vol. 15 (Boulder, Colo. : Westview, 1993), p. 352
} 
office and arrested him in relation to lawsuit number 235 of 1994/ Supreme State Security. Madani, who was 34 years old and in good health, died fortyfour hours after his arrest. The Egyptian Organization for Human Rights and the bar association contend he died of torture ${ }^{30}$.

3.3. On 26 June 1995, Mubarak flew to Addis Ababa, and while leaving the airport he and his convoy were ambushed by an Egyptian Gama'a al-Islamîya squad, led by the Sudanese Mohammad Seraj. Mohammad el-Islambouli, the older brother of Khaled El-Islambouli, also took part in the assassination attempt. Mubarak's driver managed to return to the airport and Mubarak flew back to Cairo. Sudan was openly involved in the attempt and Mohammad elIslambouli himself escaped through Sudan, to Iran, where he received political asylum.

In October 1995, 49 members of the MB were indicted and the list was headed by 'Ișâm al-Dîn al-'Eryân'31. On 19 November 1995, a suicide bombing at the Egyptian embassy in the Pakistani capital Islamabad killed 15 people and wounded more than 60 . Although three organizations claimed responsibility for the bombing, only Al-Qaeda was actually responsible. Ayman al-Zawahiri would later write his memoir in which he admitted responsibility for the bombings ${ }^{32}$.

Al-Gamâ'a al-Islamîya suffered under massive repression by the Egyptian authorities. Twenty thousand Islamists were in custody at the time. It was ready to renounce violence, but Zahawiri instigated them against the "nonviolence initiative" and, on 17 November 1997, al-Gamâ'a al-Islamîya showed its brutality with the attack at the Temple of Hatshepsut in Luxor that slaughtered 58 foreign tourists and four Egyptians.

Public opinion rose up against the Islamist movement, and Mubarak was elected as president for a fourth six-year term in 1999. After the election, Public Enterprise Sector Minister 'Atef 'Obeid was nominated Prime Minister, an office he held from October 1999 to July $2004^{33}$. 'Obeid's appointment was decided by Mubarak's son, Gamal. His administration carried out the privatization of many companies of the public sector. Through his mandate, corruption became widespread and in 2012 'Atef 'Obeid was convicted of squandering more than 700 million Egyptian pounds of public funds.

3.4. In the 2000 elections the members of the Muslim Brotherhood had to run as independent $^{34}$. They won 17 parliamentary seats, making them the largest

\footnotetext{
${ }^{30}$ http://www.derechos.org/human-rights/mena/eohr/fear.html Accessed Sept. 2013

31 Muhammad Salîm al-'Awwâ, Qaḍîyat al-ikhwân al-muslimîn 1995, Cairo: Dâr al-Shurûq, 2012.

${ }^{32}$ Fursân tahta râyat al-Nabî (Knights under the Banner of the Prophet), first published by alSharq al-Awsat, a Saudi Arabian journal, in 2001, and then in a larger $2^{\text {nd }}$ edition, by Sahab, in Riyad http://azelin.files.wordpress.com/2010/11/ayman-al-zawahiri-knights-under-the-prophetsbanner-second-edition.pdf Accessed Sept. 2013.

33 "Egypt: Mubarak picks privatization chief as prime minister" in MEED: Middle East Economic Digest;10/15/1999, vol. 43, issue 41, p. 25.

34 Al-lkhwân fî Barlamân 2000 : dirâsa tahlîlîyah li-adâ’ Nuwwâb al-lkhwân al-Muslimîn fî Barlamân 2000-2005, ed. Markaz al-Umma li-I-Dirâsât wa-al-Tanmiyah, bi-l-ta'âwun ma'a alMarkaz al-Dawlî li-I-I'lâm ; presentation Muhammad Mahdî ‘Ākif. Cairo, 2005.
} 
opposition bloc in Parliament. Opposition candidates won only 33 seats in the 444-seat Assembly, but independent candidates captured 218 of the 388 seats attributed to the ruling National Democratic Party. The Parliament was a tame organism and civil society had to express its discontent through other channels.

While the Mubarak regime tolerated syndicates, unions, business associations and service-based organizations, it continued to harass pro-democracy actors like human rights organizations and non-religious social movements, regularly accusing them of being agents of foreign regimes or "spies" seeking to destroy the Egyptian state. Two of the most famous defaming and arbitrary arrests and detention cases were against directors of human rights organizations in 1998 and 2000. The first case targeted Hafez Abu Se'ada, the Director of the Egyptian Organization for Human Rights, who was detained as a consequence of a human rights report that blamed the security apparatus for torturing and unlawfully detaining 100 Egyptian Copts in al-Koshh village in Upper Egypt in August $1998^{35}$.

The second was against Sa'ad Eddin Ibrahim (b. 1938), Professor at the American University in Cairo (AUC) and Director of Ibn Khaldun Center for Human Rights, whose organization monitored the 2000 Parliamentary elections. In the summer of 2000 he and 27 of his colleagues were arrested and subsequently tried before a state security court. Sa'ad Eddin Ibrahim was imprisoned for nine months after being found guilty in May 2001. Ibrahim was released in February 2002 pending a retrial, resentenced to seven years in July 2002, and released in December 2002. The Court of Cassation acquitted him in March $2003^{36}$.

Critical columnists were also victims of the repressive state apparatus. Columnists created public opinion contrary to the regime, revealing its corrupt practice and its machinations to remain in power. The best known columnist is perhaps 'Abdel Halim Qandil, a Nasserist journalist. Through his writings in Al'Arabî al-Nașirî, Qandil built a large following; in 2004, he helped establish Kefaya (see below) ${ }^{37}$. On 2 November of the same year, Qandil was kidnapped by anonymous thugs, beaten up and thrown out on the Suez desert road. Unfortunately, his case was not unique ${ }^{38}$. Qandil is the current (2012) editor-inchief of the private weekly Sawt al-Umma, but he has not escaped the wrath this time of the Muslim Brotherhood ${ }^{39}$.

\footnotetext{
${ }^{35}$ Reported by the Egyptian Organization for Human Rights, www.eohr.org , and Féderation Internationale des Droits de l'Homme, FIDH: http://www.fidh.org/

36 Reported by the Ibn Khaldoun Center for Development Studies, http://www.ibnkhalduncenter.org/

For Sa'ad's Eddin short biography, cf. http://encyclopedia.jrank.org/articles/pages/5738/lbrahimSaad-Eddin-1938.html Accessed Sept. 2013

37 'Abd al-Halîm Qandîl published several books: Al-Ayyâm al-Ukhrà (The Other Days), Al-Ra'îs al-Badil (The Alternative President), and Kart Ahmar li-l-Ra'îs (Red Card for the President).

${ }^{38}$ For instance, Mohammad El Sharqawi in 2006, Kamal Murad in 2008, see The Arabic

Network for Human Rights Information:

http://lib.ohchr.org/HRBodies/UPR/Documents/Session7/EG/ANHRI_UPR_EGY_S07_2010_ArabicNetworkforHumanRi ghtsInformation.pdf Accessed Sept. 2013.

39 http://english.ahram.org.eg/NewsContent/1/0/51859/Egypt/Dozens-protest-charges-against-newspaper-editor-cr.aspx Accessed Sept. 2013.
} 
3.5. Mubarak's regime took a new direction around 2000 when Gamal, the second son of the president, joined the National Democratic Party and started a skyrocketing political career. Within less than two years, the issue of tawrith, "hereditary transmission" or "inherited rule" began to surface. Mohammad Hasanayn Haykal spoke on the occasion of the fiftieth anniversary of the July Revolution at the American University in Cairo. He referred to the rumor about tawrith that was spreading throughout Egyptian society and rejected tawrith, saying that Egypt is a republic ${ }^{40}$. Nevertheless, the Constitution was amended in 2007 to prevent any legal obstacles on the road to the presidency of Gamal Mubarak $^{41}$. Western media such as the New York Times in 2003 openly sympathized with the heir ${ }^{42}$.

The threat of an hereditary rule triggered a reaction against the regime. The outcry Kefaya Mubarak! "Enough with Mubarak" gave the name to an oppositional movement that made its debut on the national stage on 12 December 2004 as the embodiment of the anti-tawrîth camp. Kefaya fused different strands of opposition to Mubarak as no movement had before ${ }^{43}$. A key instrument for its work has become the internet, where it had its own web site which is no longer accessible since February 2013. It is there where the manifesto of the movement was published ${ }^{44}$.

$$
\text { بيان تأسيس كفاية }
$$

We, the undersigned, are citizens of Egypt; are part of its rich social texture; and are active in its public life in different arenas: intellectual, civic, political, cultural, and unionist. We come from different walks of life and together represent Egypt's rich political diversity. We believe there are two grave dangers which beset our nation today. They are two sides of the same coin, each nourishing the other, and neither curable alone:

First, The odious assault on Arab native soil through:

\section{The US occupation of Iraq;}

2. The Zionist devastation daily wreaked on the Palestinian people bordering on a holocaust; and

3. The designs, including the Broader Middle East Initiative, to recast the map and fate of the Arab region and people.

\footnotetext{
${ }^{40}$ Mohammad Hassanein Haykal gained the favor of Mubarak as his book Mubârak wazamânu-hu shows (Cairo: Dâr al-Shurûk, 2012).

${ }^{41}$ Various amendments strengthened President Mubarak's hold on the presidency. http://www.carnegieendowment.org/files/egypt_constitution_webcommentary01.pdf Accessed Sept. 2013.

42 http://www.nytimes.com/2003/12/21/international/middleeast/21EGYP.html?pagewanted=all Accessed Sept. 2013.

${ }^{43}$ Nadia Oweidat et al., The Kefaya movement : a case study of a grassroots reform initiative, Santa Monica CA: RAND, 2008.

${ }^{44}$ http://www.harakamasria.org/ Accessed Dec. 2012.
} 
All civil and political efforts must be amassed and coordinated to ward off this peril to the future survival of the Arab peoples and society.

Second, The repressive despotism that pervades all aspects of the Egyptian political system and want of democratic governance. Political reform constitutes:

1. Termination of the current monopoly of power at all levels, starting with the seat of the President of the Republic;

2. Effecting the rule of law as the supreme source of legitimacy;

3. Elimination of the current unfounded monopoly and squandering of the wealth of the nation; and

4. Regaining Egypt's legitimate and significant, if now lost, place amongst the family of nations.

What to do: The concrete steps in our route to a homeland of democracy and progress for Egyptians call for immediate measures towards:

1. Breaking the hold of the ruling party on power and all its instruments;

2. Cessation of the Emergency Law now in effect for a full quarter century;

3. Cessation of all laws which constrain public and individual freedoms; and

4. Effecting constitutional reform to

a. Allow for direct election by citizens of the President and Vice President of the Republic from among several candidates;

b. Limit the tenure of the President to a period not to exceed two terms;

c. Limit the almost absolute sanctions and prerogatives currently entrusted to the office of the President of the Republic

d. Separate the Legislative, Judiciary, and Executive Powers, and elaborate independent checks and balances for each;

e. Ensure the unsanctioned freedom of association; the formation of political parties; and the publication of newspapers;

f. Remove the current state of sequestration imposed on syndicates; and

g. Conduct fair and real parliamentary elections under the supervision of the Supreme Judicial Council and State Council for all steps, from citizen registration to the publication of the election results.

The manifesto was released in August 2004 and received supporting signatures from 300 prominent intellectuals. Tareq al-Bishri, a respected judge and a prolific writer, was appointed as an adviser to the movement ${ }^{45}$. Bishri distinguished four main trends in Egyptian politics in the seventies and eighties:

\footnotetext{
${ }^{45} \mathrm{He}$ is the author of many influential publications, such as Naḥw tayyâr asâsî li-I-umma, Cairo. Dâr al-Shurûq, 2011.
} 
Islamic, Nationalist, Liberal and Socialist ${ }^{46}$, and pleaded for "a national project" bringing together the different movements.

George Ishaq was the first coordinator general of the movement; the coordinator used to be the official speaker. In January 2007, 'Abdel Wahab alMessiry was elected, but he passed away in July 2008. He was succeeded by the above-mentioned 'Abdel Halim Qandil, a Nasserist activist and former coeditor-in-chief of Al-Karâma newspaper.

'Abdel Halim Qandil collected a number of his newspaper articles in a book published in 2010 under the provocative title "The substitute president". ${ }^{47}$ One of them carries the headline "The initiative of Kefaya" (5 October, 2009) and summarizes the movement in three slogans: boycott, replacement and disobedience: Boycotting the elections, replacing Mubarak and civil, peaceful disobedience.

Kefaya stretched out also to Islamist activists: Magdy Ahmed Hussein, president of the Islamist Egyptian Labor Party, was a member of the People's Assembly from 1987 to 1990 . He was arrested many times, the last time in 2009, until he was liberated in $2011^{48}$. Mohammad al-Ashqar, a Nasserist Karama Party activist, is currently the coordinator general of Kefaya ${ }^{49}$.

Salah Montaser writes that three factors were effective in toppling the regime: tawrîth (inherited rule), corruption and kefaya ${ }^{50}$. Kefaya made Egyptians overcome fear. Kefaya was the origin of multiple oppositional movements among workers, doctors, and teachers. Kefaya successfully mobilized wide segments of Egyptian society, although Kefaya's diversity primarily reflected longstanding political trends in Egypt: the leftist and Islamist.

The Internet was decisive for the achievements of Kefaya that successfully exploited information technology. Nevertheless, in a nation with only six million Internet users, there are limits to the effectiveness of Internet strategies. The Mubarak regime resorted as usual to violence to choke the movement. Using its capacity to manipulate laws and deploy security forces, it aimed at weakening Kefaya.

3.6. The Egyptian presidential election of September 2005 was the first contested presidential election in Egypt's history. Many voices could be heard complaining about fraud. After constitutional amendments were enacted, the election of the president of the republic took place by direct secret ballot from among all citizens who had the right to vote. Hosni Mubarak ran against Ayman Nour, of the Ghad Party and against Nu'man Goma'a. Official results gave Mubarak $88.6 \%$ of the vote; complaints about fraud were swiftly dismissed

\footnotetext{
${ }^{46}$ Naḥw tayyâr..., p. 11.

47 Al-ra'îs al-badîl, Dâr al-thaqâfa al-gadîda, 2010.

48 http://www.magdyhussein.com/site/ Accessed Sept. 2013.

${ }^{49}$ Besides Mohammad 'Abdel 'Aziz is the youth coordinator of the Egyptian Movement for Change .

${ }^{50}$ Al-șu û̀d wal-l-suqût, p. 160.
} 
In this way Mubarak won his fifth reelection after 24 years in power; many voices could be heard against his perpetuation in office. Kefaya demonstrated on 21 February 2005 in front of Cairo University ${ }^{51}$.

In the 2005 parliamentary elections (November-December), the Brotherhood's candidates, who had to run as independents because of their exclusion as a political party, won 88 seats $(20 \% \text { of the total })^{52}$. The legal opposition won only 14 seats. The results of the 2005 election were skewed by the banning of what was assumed to be the main opposition party, the Muslim Brotherhood, and almost insurmountable obstacles for independent candidates.

Mubarak called voters to a referendum on constitutional amendments on 26 March $2007^{53}$. The constitutional changes empowered the president to dissolve Parliament without holding a referendum, to suspend civil protections in cases the president deems associated with terrorism, and to limit the role of judges in monitoring future elections. Oppositional parties, the Muslim Brotherhood and the Judges Club criticized the reform and the way it was carried out.

Shortly before the referendum, the former presidential candidate Ayman Nour was arrested and 212 public personalities from all across Egypt signed a manifesto denouncing his arrest and the persecution of his Ghad (Tomorrow) party as well as that of the Muslim Brotherhood, who were all being referred to military courts ${ }^{54}$.

3.7. The last decade of Mubarak's rule witnessed a wave of worker unrest following the installation of Mubarak's cronies to powerful political and economic posts. Two large strikes stopped the Mișr Spinning and Weaving Company in Mahalla al-Kubra, in December 2006 and January 2007. The mammoth factory was the flagship of the state-owned sector, employing some 24,000 workers. The strike made waves through all of Egyptian society, and Kefaya made common cause with the strikers, showing its solidarity by staging a demonstration on January 27 . The workers succeeded with their claims and their victory reverberated throughout the political arena.

The "Sixth of April Youth Movement" can be seen as one of its reverberations. On 23 March 232008, a small group of young Egyptian activists launched a Facebook page in support of a planned textile workers' strike in the city of Mahalla al-Kobra to protest low wages and high food prices. The group's leaders included 27-year-old Esraa Abdel Fattah Ahmed Rashid and 27-yearold Ahmed Maher, both former members of the youth wing of the Ghad party.

On 6 April 2008, thousands of workers rioted. Egyptian security police suppressed the revolt. Esraa Rashid was arrested and jailed for more than two weeks; she became known as "the Facebook Girl" ${ }^{55}$ Esraa is now projects

\footnotetext{
51 http://weekly.ahram.org.eg/2005/731/eg10.htm Accessed Sept. 2013.

52 Noha Antar, "The Muslim Brotherhood's Succes in the Legislative Election in Egypt: 2005 :

Reasons adn Implications". EuroMesco Paper, October 2006, issue n 51.

$53 \mathrm{http}: / /$ carnegieendowment.org/2007/03/23/egypt-s-constitutional-amendments/2p2x Accessed Sept. 2013.

54 http://www.ikhwanweb.com/print.php?id=943 Accessed Sept. 2013.

55 http://www.gopetition.com/petitions/free-esraa-abdel-fattah/signatures-page2.html Accessed Sept. 2013.
} 
manager for the Egyptian Democratic Academy, a non-governmental organization that promotes the use of new media tools to foster democracy ${ }^{56}$.

The "Sixth of April Youth Movement" survived the repressive grip of the regime. On 6 April 2010, a commemorative demonstration by the movement was violently put down by the police; a week later, Kefaya protested against the police brutality in the earlier demonstration and also fell victim to the same brutality $^{57}$.

Ahmed Maher, a civil engineer, remains 6 April's leader, and Mohammad 'Adel and Amal Sharaf are now his main associates ${ }^{58}$. The movement was a key player in the Tahrir occupation that eventually toppled the regime.

Women played a decisive role in this youth movement, and were also important players in the opposition to Mubarak ${ }^{59}$. An unknown girl, Asmaa Mahfouz, called on Egyptians to demand their human rights and to voice their disapproval of the regime in a video blog posted to Facebook on 18 January $2011^{60}$. Her call helped to spark the revolution.

3.8. The Muslim Brotherhood carried on its struggle to gain power and influence in Egypt's public life. The regime reacted aggressively and mistreated its members. In December 2006 Khairat al-Shater was arrested again along with 12 other Brotherhood leaders in the so-called case of "Al-Azhar Militia" ${ }^{61}$ In 2007, Malek and Shater were also accused of money laundering and their assets were confiscated.

In August 2007, in an attempt to show a politically acceptable face, the Muslim Brotherhood published its first manifesto for a political party. The document contained some very retrograde ideas regarding the rights of women and Copts and the creation of a body of clerics that would wield supreme power. The document roused the anger of multitudes of Egypt's intellectual, cultural and political elites ${ }^{62}$.

As for the leftist opposition to the regime, Kefaya became the strongest coalition force. On 12 December 2009 it re-emerged in public, demonstrating before the Supreme Court against proposed constitutional amendments ${ }^{63}$. By 2009, parties and other organizations in the Kefaya coalition included :

al-Wafd (Delegation), a nationalist liberal political party, the most popular and influential party for a period in the 1920s and 30s;

\footnotetext{
${ }^{56}$ http://www.glamour.com/inspired/women-of-the-year/2011/esraa-abdel-fattah Accessed Sept. 2013.

${ }^{57}$ http://www.thefreelibrary.com/Kefaya+protestors+clash+with+police.-a0223789530 Accessed Sept. 2013.

$58 \mathrm{http}: / / 6 a p r i l m o v e . b l o g s p o t . c o m . e s /$ and http://www.6april.org/ Accessed Sept. 2013.

59 http://web.archive.org/web/20130620095228/http://www.npr.org/2011/02/04/133497422/Women-Play-Vital-Role-InEgypts-Uprising Accessed Sept. 2013.

$60 \mathrm{http} / / /$ www.youtube.com/watch?v=zrTmwwpwBFw Accessed Sept. 2013.

${ }^{61}$ In 2006 a group of Brotherhood-affiliated students dressed in militia outfits held a martial demonstration on Al-Azhar's campus.

${ }^{62}$ Nathan J. Brown - Amr Hamzawy,"The Draft Party Platform of the Egyptian Muslim Brotherhood: Foray Into Political Integration or Retreat Into Old Positions?" Carnegie PAPERS. Middle East Series (Washington DC), Number 89, January 2008.

63 http://www.aljazeera.com/news/middleeast/2007/03/200852513218704328.html Accessed Sept. 2013
} 
al-Tagammu;, (Assembly) ${ }^{64}$, National Progressive Unionist Party, publishes the newspaper Al-Ahâlî;

al-Nașirî (Nasserist), Arab Democratic Nasserist Party, al-‘Arabî;

al- 'Amal (Labor), See footnote ${ }^{65}$.

al-Karâma (Dignity) ${ }^{66}$, Dignity Party, publishes al-Karama;

al-Wasat (Center) ${ }^{67}$, Center Party, moderate Islamist political party;

and Gamâ'at al-lkhwân al-Muslimîn (Muslim Brotherhood) as well as the National Association for Change with Mohammad ElBaradei ${ }^{68}$, the National Coalition for Reform and Change ${ }^{69}$, and the Popular Campaign for Change.

Nobel Laureate Mohammad EIBaradei returned to Egypt in 2009 after stepping down from his twelve-year tenure as director general of the International Atomic Energy Agency. Kefaya greeted his return with a communiqué on February 19, 2010 in which it conveyed its desire for cooperation in order to build a wide alliance of oppositional forces ${ }^{70}$.

EIBaradei led a popular movement to collect one million signatures to demand reforms, and started the National Association for Change ${ }^{71}$. In April 2012, ElBaradei launched the Constitution Party, a new political party which he said would be above ideology.

In November-December 2010, there were elections for the People's Assembly. Kefaya and the National Association for Change (ElBaradei) called for a general boycott. The NDP won 420 seats plus 53 others as independent out of a total of 518. Its sweeping victory occurred amid allegations of fraud, electoral rigging, and political repression. Elections in Egypt were never free of fraud, but the fraud in the 2010 elections exceeded any imaginable bounds ${ }^{72}$. But both NDP members and their critics agreed on one assessment: The triumphal outcome was the work of the NDP's new guard, headed by Gamal Mubarak and benefitting from the decisive role of Ahmed 'Ezz, the party's secretary of organization and a steel tycoon ${ }^{73}$. However, Gamal Mubarak, 'Ezz and the new crew overestimated their abilities to manipulate the country and did not pay

\footnotetext{
${ }^{64}$ Established in 1976, a left wing party. It is lead by Muhammed Refa'at Al Sa'id and brings together about 22,000 members.

${ }^{65}$ Al-'Amal party was founded in September 1978, as an extension to Misr Al-Fatah movement, which was founded in 1933 by Ahmed Hussein. Reestablished in 1978, headed by Ibrahim Shoukry, (the Vice President of Misr Al-Fatah movement and the Socialist party). Moreover, the party has declared its Islamic orientation in 1986.

${ }^{66}$ The party adopts the Arab nationalist ideas and brings together Nasserists, intellectuals and a number of Egyptian politicians with center left ideologies.

${ }^{67}$ It was founded by Abou El-'ela Mady in 1996 as a splinter group of the Muslim Brotherhood.

68 Sarah Carr, "Kefaya reagroups with new 'Coalition for Change'," published in Daily News Egypt, on 21 - 01 - 2009, http://www.masress.com/en/dailynews/100993 Accessed Sept. 2013.

${ }^{69}$ The National Coalition for Democratic Change was born in June 2005; its founder was former Prime Minister 'Aziz Sedqi, and former Local Administration Minister Yehya El- Gamal.

70 'Abd al-Halim Qandil, Al-Ra'îs al-Badîl , pp. 236-237.

${ }_{72}^{71} \mathrm{http}: / /$ news.bbc.co.uk/2/hi/middle_east/8534365.stm_Accessed Sept. 2013.

72 Sa'ad Ebrahim wrote "Fraud has became the way of life of the NDP", http://today.almasryalyoum.com/article2.aspx?ArticlelD=280567\&IssuelD=1981 Accessed Sept. 2013.

${ }^{73}$ Mona el-Ghobashy in The Journey to Tahrir. Revolution, and Social Change in Egypt, ed. Jeannie Sowers and Chris Toensing (London - New York: Verso 2012), p. 146-147.
} 
attention to the widespread unrest in Egyptian society. Since the November elections were a trial run for the 2011 presidential elections, their miscalculation became a fatal trap.

3.9. On 6 June 2010, the blogger Khaled Sa'id had been sitting on the second floor of a cybercafé in Alexandria. Two detectives from the Sidi Gaber police station entered the premises and arrested him. Sa'id had posted a video of police allegedly splitting up drugs confiscated in a bust on 6 June 2010 .

Multiple witnesses testified that Sa'id was beaten to death by the police, who reportedly hit him and smashed him against objects as he was led outside to their police car. The owner of the internet cafe in which Sa'id was arrested stated that he witnessed Sa'id being beaten to death in the doorway of the building across the street.

A large movement came together around the "We Are All Khaled Sa'id" Facebook page, https://www.facebook.com/EIShaheeed (accessed Sept. 2013). Google executive Wael Ghoneim started the page anonymously in early June; by mid-month, the page had 130,000 members, and as of 22 January 2011, the number hit 380,000 members, making it Egypt's largest and most active online human-rights activist group ${ }^{74}$. Ghoneim was detained during the protests leading to the Revolution; he has since recorded his experience in a successful book $^{75}$.

The assassination of Khaled Sa'id by police forces was another instance in a long chain of abuses committed by the security forces in Egypt. Protests in Alexandria and across the world apparently did not spur reform by November, when Ahmed Shab'an was found dead in a gutter after having been arbitrarily arrested by police in the same district. In December, Alexandrian police allegedly beat to death Mustafa 'Attia ${ }^{76}$. After the Revolution of January, the two detectives who beat Khaled Sa'id to death were detained and indicted. On 26 October 2011, both plaintiffs were found guilty of manslaughter and were sentenced to seven years.

4. The Revolution of January 2011 did not come out of the blue, but the manner in which it developed could not have been anticipated. "The reality was that Egyptians had been practicing collective action for at least a decade, acquiring organizational experience in that very old form of politics: street action" ${ }^{77}$

The developments of the January Revolution are quite well known, thanks to the permanent monitoring of the events via television and Internet channels.

\footnotetext{
74 http://www.egyptindependent.com/news/we-are-all-khaled-saeed-redefining-politicaldemonstration-egypt Accessed Sept. 2013.

${ }^{75}$ Al-thawra 2.0, $3^{\text {rd }}$ ed. Cairo: Dâr al-Shurûq, 2012.

76 Sarah Carr, "Egypt's democratic façade continues to crumble" in Freedom at Issue, December 30, 2010, http://blog.freedomhouse.org/weblog/2010/12/egypts-democracycontinues-to-falter.html Accessed Sept. 2013.

77 Mona el Ghobashy, in The Journey to Tahrir, p. 23.
} 
The Police Day became the "day of rage" because of the long experience of the Egyptian people with street action.

A key organizer of the 25 January action was the Sixth of April Youth Movement. Kefaya was also a main actor in those days that changed Egypt. The Muslim Brotherhood came later and joined the demonstrators on Tahrir, helping them win the so called "Battle of the Camel". However the first free elections in the country after 60 years gave the victory to the Muslim Brotherhood. The new parliament and senate have an overwhelming Islamist majority, and the president of the republic is the former chairman of the Freedom and Justice Party (FJP) ${ }^{78}$.

This article purposely ends on June 2012, over one year ago. Its purpose is to reflect upon a tragic and at the same time, confident history of oppositional movements in Egypt since the country abandoned formal democracy in 1952. I have tried to show the various groups of the Islamic opposition which doubtless is the longest standing force, but I have also pointed out the strength and the leadership of the lay movements that brought democracy back to the country. And if in June 2012, it was difficult to believe in an agreement between these two primary forces, in June 2013, after one year of abusive, bigoted MB government, any agreement is totally out of the question.

\footnotetext{
${ }^{78}$ The FJP was founded by the Muslim Brotherhood in the wake of the 2011 Egyptian revolution.
} 